\title{
The quality of governance and economic growth in Croatia
}

Bađun, Marijana

Source / Izvornik: Occasional Paper Series, 2006, 10, 1 - 32

Journal article, Published version

Rad u časopisu, Objavljena verzija rada (izdavačev PDF)

https://doi.org/10.3326/ops.29

Permanent link / Trajna poveznica: https:/urn.nsk.hr/urn:nbn:hr:242:907162

Rights / Prava: Attribution-NonCommercial-NoDerivatives 4.0 International/ImenovanjeNekomercijalno-Bez prerada 4.0 međunarodna

Download date / Datum preuzimanja: 2023-04-26

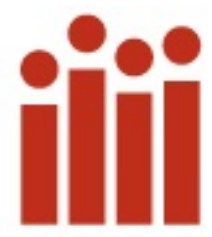

Repository / Repozitorij:

Institute of Public Finance Repository

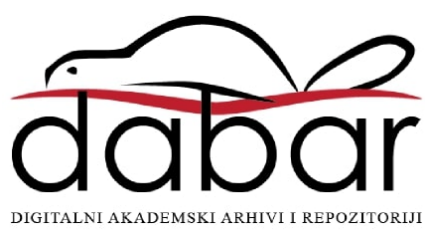


THE QUALITY OF GOVERNANCE AND ECONOMIC GROWTH IN CROATIA

Marijana Bađun

Occasional Paper No. 29

June 2006 


\title{
THE QUALITY OF GOVERNANCE AND ECONOMIC GROWTH IN CROATIA*
}

\author{
Marijana Bađun \\ Economics Faculty, Zagreb \\ mbadjun@efzg.hr
}

\begin{abstract}
The objective of this paper is to show the justification and importance of explicit inclusion of quality of governance in the debate on economic growth in Croatia. Governance is defined as the manner in which the state employs its power in handling the institutional environment, thus affecting the accumulation of economic growth factors. Although there are numerous elements in the quality of governance, this paper places the emphasis on the whole on two of them: the rule of law and the quality of the public administration. In pursuit of its objective, the paper first of all considers the links between governance and economic growth in growth theory and empirical research to date. After that an econometric (panel) analysis of quality of governance and economic growth on a sample of EU countries and Croatia, Bulgaria and Romania (EU accession candidate countries) is performed, and then changes in the quality of governance in Croatia are considered. From a comparison of the values of indicators of the rule of law and quality of the public administration, and the dynamics and nature of reform in the administration of justice and the civil service, it appears that those in whom power is vested in Croatia are more focused on rent-seeking than is the case in the average of EU countries. Institutional shortcomings have affected the current level of real per capita GDP in Croatia, and more rapid and effective reforms of the justice and public administration sectors, as well as fighting corruption and boosting democracy (as mechanism for controlling those in whom power is vested) would have a positive effect on future economic growth.
\end{abstract}

JEL Classification: $\mathrm{O} 470$

Key words: governance, economic growth, Croatia, rule of law, public administration

*This article is published in Croatian in the journal "Financial Theory and Practice", 29(4), 2005, pp. 337-367, and is downloadable in Croatian from: http://www.ijf.hr/FTP/2005/4/badjun.pdf, and also in English from: http://www.ijf.hr/eng/FTP/2005/4/badjun.pdf 


\section{TABLE OF CONTENTS}

\begin{tabular}{l} 
1. Introduction \\
\hline
\end{tabular}

2. Governance and economic growth 6

2.1 Governance and theoretical models of growth 6

$\begin{array}{ll}2.2 \text { Empirical findings accounts } & 7\end{array}$

3. Econometric analysis of the quality of governance and 9 economic growth

3.1 The rule of law and economic growth 12

3.2 Quality of public administration and economic growth 13

4. Changes in the quality of governance in Croatia 17

5. Conclusion 21

$\begin{array}{ll}\text { References } & 22\end{array}$

$\begin{array}{lr}\text { Annex } & 25\end{array}$ 


\title{
THE QUALITY OF GOVERNANCE AND ECONOMIC GROWTH IN CROATIA
}

\author{
Marijana Bađun**
}

\section{INTRODUCTION}

In previous investigations of the quality of governance ${ }^{1}$ in Croatia it was established that according to indicators of the rule of law and quality of the public administration, Croatia considerably lags behind the EU-15 average, and also behind the new members of the $\mathrm{EU}^{2}$, though in this case there is a somewhat smaller gap (Ott, 2004). The World Bank (2003) identified poorly defined laws protecting property and creditors and the poor functioning of the justice system as the main obstacles in the way of a rapid and sustainable growth for Croatia. For the removal of these obstacles, legal reforms and, still more importantly, effective reform of the public administration are required. In 2003, the EBRD also accorded prime position, within the key reforms in Croatia, as well as in Bulgaria and Romania, to the strengthening of the capacity of the public administration and increasing the effectiveness of the judiciary so as to create a propitious economic environment. The frequent mention of the rule of law and the quality of the public administration by international organisations is very understandable, for these two areas have been shown to be the basic weaknesses in the institutional development of the transitional countries (Shleifer, 1997; Murrel, 2002).

In spite of criticisms of international organisations, which might be said to have arrived later than they should have ${ }^{3}$, it would seem that the authorities in Croatia do not understand fully quite how much institutional weaknesses have affected the current size of real per capita GDP in Croatia, and what the results of failure to carry out the said reforms on future economic development might be. The objective of this paper is to show that it is reasonable and important explicitly to introduce the quality of governance into the debate on the economic growth of Croatia. Here we shall define governance as the manner in which government uses its power in the management of the institutional environment, hence affecting the accumulation of the factors of economic growth. ${ }^{4}$ In accordance with this, good governance will be considered the kind of governance that contributes to economic growth. Although there are numerous elements that together constitute quality of governance, in this work particular emphasis will be placed on two of them: the rule of law and the quality of the public administration, for the reasons already cited. The rule of law in the paper means a system in which all citizens are equal before the law and in which every breach of the law is consistently sanctioned. Good public administration is considered the kind of public administration that is effective in the obviation of barriers in the way of enterprise and investment (a low

\footnotetext{
** The writer gratefully acknowledges the very useful comments of Professor Vojmir Franičević, Professor Steve Pejovich and the three anonymous peer reviewers and takes all responsibility for any errors there still might be.

${ }^{1}$ When in economic literature governance is mentioned, the reference is often to corporate governance. In this work however, public governance is meant.

${ }^{2}$ The paper does not take into consideration Cyprus and Malta, but only the Czech Republic, Estonia, Hungary, Latvia, Lithuania, Poland, Slovakia and Slovenia.

3 The delay is related to the shortcomings of the Washington consensus (v. e.g., Ahrens and Meurers, 2000)

${ }^{4}$ Institutions represent the rules of the game in society, the human-created constraints, that shape their interaction and give the structure to incentives in exchange (North, 1994: 360).
} 
degree of bureaucratisation $)^{5}$, the officers of which do not abuse their power for the sake of private benefit (the absence of corruption). It is clear that there are other criteria as well according to which the quality of public administration might be evaluated, but they are not the subject of this paper.

At the very beginning of the paper we shall consider the link between governance and economic growth in the theory of growth and in empirical research to date. After that we shall carry out an econometric analysis of the quality of governance and economic growth using a sample of EU countries, and Croatia, Bulgaria and Romania (all EU candidates), and then shall consider how fast changes in the quality of governance are occurring, and the nature of these changes. According to this we shall be able to evaluate how much those in whom power is vested in Croatia are focused on their own benefits, and how much on the creation of a growth-incentivising environment.

\section{GOVERNANCE AND ECONOMIC GROWTH}

Throughout history there have been numerous attempts to set economic growth moving, but only a few of them have actually succeeded. Seeking the most frequent common denominator of all examples of the frustration of growth the historian Jones noticed that this was the universally existing aspiration towards rent-seeking, i.e., the use of political means, and indeed of violence, "to take more out of the kitty than would be justified by one's own contribution" (Jones, 2003:XXXV). When this is joined to North's claim (1990) that institutions are the basic determinant of the long-term high performance of an economy, then the importance of the quality of governance in economic growth, especially over the long term, can be discerned.

\subsection{Governance and theoretical models of growth}

Although governance did exist in descriptive studies of economic growth and in particular in the domain of economic history, it has been neglected in the standard growth models. The Solow model for example, is grounded on numerous assumptions, one of them being that property rights are secure. Thus the main deficiency of this model from the standpoint of governance is that it does not take into account any shortcomings in the quality of governance, assuming that they do not exist. Although the so-called neoclassical models of growth are still current in economics and although they have explained a great deal in the mechanism of growth, they still do not give a fundamental explanation of it (Acemoglu et al., 2004:1). The issue that the Solow model has not addressed is why in some countries individuals invest more in physical and human capital, or why they invest more resources into innovation than in some other countries.

The currently leading hypothesis (within the new theory of growth) explaining differences in GDP characteristics among countries relates to social infrastructure, a concept similar to governance. ${ }^{6}$ Hall

\footnotetext{
${ }^{5}$ The bureaucracy in this context has a negative connotation and relates to unnecessarily complications and to sluggishness in the performance of tasks, to the huge amount of procedures and the absence of information.

${ }^{6}$ The difference in the signifier comes from different researchers at almost the same time having found in existing models of growth the same shortcoming and then called it by different names. Social infrastructure is a concept that appears in macroeconomic textbooks, and public governance is mentioned in very many empirical investigations, particularly in those spurred by the World Bank. It is important to mention that this work, in defining public governance, or governance per se, stresses the government as the primary factor creating the business and investment environments. Thus social infrastructure is actually a broader concept than governance, for it also includes informal networks.
} 
and Jones (1999) take social infrastructure to be the institutions and government policy that encourage investment and production, and not consumption and rent-seeking. ${ }^{7}$ By the creation of appropriate institutions, the government reduces uncertainty and transaction costs, thus enlarging trade efficiency, encouraging specialisation and incentivising investment in physical and human capital and ideas. Naturally, it is precisely this power of creating and carrying out laws that enables the government itself to become the main agent in rent-seeking.

Social infrastructure, like quality of governance, can also affect the form of investment that is undertaken. For example, in an environment with insecure property rights it is more profitable to invest in trade than in some innovative long-term projects involving the slow accumulation of capital. Similarly, if the danger of being penalised for taking bribes in the administration is nugatory, individuals will endeavour to acquire skills enabling them to obtain employment in the civil service rather than knowledge that will advance production.

Unfortunately, no well-elaborated theoretical model of growth including governance or even social infrastructure as integrated concepts exists. Instead of that, intuition and historical experience tend to prevail, and from these stems empirical research.

\subsection{Empirical findings}

Until very recently it was considered impossible econometrically to confirm the hypothesis that quality of governance affects economic growth for "institutions cannot be seen, felt, touched or measured" (North 1990: 107). Since quality of governance has at the theoretical and political levels become an increasingly acknowledged determinant of the magnitude and rate of growth of GDP, so the number of investigations of the topic have increased. Their popularity has been enhanced by the expanding availability of information for many of the dimensions of governance. In econometric research there has been an endeavour to find various factors incentivising investment in physical and human capital, and research and development expenditure, or quite simply attempts have been made to explain economic growth without devoting too much attention to the channels through which it was effectuated. A great part of the research directly mentions governance, and in others it is seen through the institutions. However, there is no work covering all the dimensions of governance, each author concentrating rather on just a few of them. Mention is most often made of the rule of law, protection of property rights, effectiveness/quality of the civil service, corruption, democracy, political stability and the magnitude of administrative obstacles.

The findings of such investigations might be summed up in a few points:

- there is a positive correlation among many of the elements of quality of governance and long-term rates of growth in GDP (Mauro, 1995; Knack and Keefer, 1995; Rodrik, 1997; Evans and Rauch, 1999; and so on);

- poor governance is a characteristic of countries that have low levels of real per capita GDP (Hall and Jones, 1999; Kaufmann and Kraay, 2002; Acemoglu et al., 2004);

- growth can be generated without major institutional changes (Glaser et al., 2004) but good institutions are necessary for the maintenance of long-term rates of growth (Rodrik, 2004);

\footnotetext{
${ }^{7}$ Rent-seeking can be defined as a reallocation of property rights via political intervention, and not as market competition (Kasper and Streit, 1998:39). Politicians and public servants, like all other people, tend to follow their
} 
- improved governance is not an automatic side-effect of a country's increased wealth (Kaufmann and Kraay, 2002);

- the marginal contribution of institutional improvements is greater in transitional countries (Moers, 1999);

- the rule of law is the most important quality of governance for growth in the transitional countries (Campos, 2000).

Objections to econometric research into the quality of governance and economic growth are largely related to the data used in it. Among such critiques, mention might be made of:

- the data are imprecise and subjective because there are no direct measures of governance;

- it is not always possible to determine how well they distinguish between perceptions of poor institutions and poor economic performance;

- many indicators describe the economic environment for foreigners better than for domestic investors, since they are actually designed for them in the first place;

- the existing indicators do not reflect any permanent characteristics of institutions, being rather the results of politics in the country in the immediately preceding period;

- very broad measurements are made of some of the dimensions of governance;

- in connection with commercial agencies such as Political Risk Services, ${ }^{8}$ the transparency of index formation is fairly low - the methodological value of such items is dubious for nowhere is there any indication of the principles according to which the consultants forming the index for some country are chosen.

In spite of these criticisms, especially those that relate to subjectivity, it is a fact that there are commercial agencies that make very good earnings by selling indicators of governance quality, which means that they must be giving useful information to potential investors. It can also be said that in a democratic society perceptions are fairly important. For an investor, the sense of security provided by the existence of some law is of considerable importance; subjective indicators evaluate how much formal institutions are applied in reality. ${ }^{9}$ In recent times aggregate indicators have frequently been used based on several sources and hence are so much the better. Of the actual indicators, though, a more important issue is causality, i.e., feedback of growth on institutions, which still has not been satisfactorily handled. It is not desirable facilely to conclude that institutions cause growth, rather it is better to say that they facilitate it. Among other drawbacks of existing investigations, we would foreground the following:

- the problem of multicolinearity;

- the connection between governance and growth may not always be linear and yet in the models this is always assumed;

- as for comparison with "similar" countries, the criteria cannot be only per capita GDP, but certain other factors, such as dependence on trade, geographical position, cultural and historical inheritance;

\footnotetext{
own interests, which do not necessarily coincide with the interests of the electorate.

${ }^{8}$ Political Risk Services (2005) publishes its International Country Risk Guide (ICRG), which contains numerous indicators of the quality of governance. It is interesting to see that the price of the ICRG, with its monthly updates, comes to $\$ 4,595$ p.a.

${ }^{9}$ In some future research it would be necessary to see if sensitivity to institutional shortcomings increase in parallel with economic development and whether this in turn affects subjective governance quality indicators. Also needing to be investigated is whether after all some peoples are more pessimistic than others, and how much perceptions differ from reality.
} 
- the assumption that the same regression models work for rich and poor counties is on the whole inaccurate (a problem known as parameter heterogeneity);

- insufficient attention is given to other independent variables that are included in the model, which can considerably affect the results - it is necessary to vary the control variables and only then to draw conclusions;

- it may happen that precisely those variables that are explained by both GDP and institutions are excluded, in which case an apparent regression arises;

- researchers who have observed short periods of time have tended to ignore cyclical trends in GDP.

Although the criticisms are numerous, it would be unreasonable a priori to reject econometrics in the investigation of economic growth, for it provides new solutions year after year, the data are improved, and in addition econometrics draws attention to potentially interesting relations of the variables, which then need to be interpreted. ${ }^{10}$ In spite of that, it would still be desirable to supplement econometric studies with the analysis of individual economies and additional researches by political and social scientists and institutional economists - of all, in fact, who are interested in the area. In line with this, the current paper will first of all carry out an econometric analysis, and after that will concentrate on an individual economy - the Croatian.

\section{ECONOMETRIC ANALYSIS OF THE QUALITY OF GOVERNANCE AND ECONOMIC GROWTH}

In all the countries of CE Europe and in the Baltic lands, the transition to a market economy led to an initial decline, sometimes dramatic, in real per capita GDP, and by 2001, not all the countries had regained the level of $1990 .{ }^{11}$ Among such countries was Croatia. The question is very reasonably asked why some transitional countries developed more rapidly than the others when all went through a similar process of reform: the stabilisation of the economy, market liberalisation and privatisation.

The institutional vacuum that ensued after the fall of socialism was at the point of origin of the successes and failures of economic reforms (Campos, 2000). It was shown that at the beginning of the transition the minimum institutions for the development of the market that would restrict unwanted forms of human conduct and reduce insecurity had to exist. Transition brought with it a set of exogenous shocks that gave greater power to certain groups in society, and their ability to organise depended on the institutions that happened to exist at the time. Institutional deficit, the deficiency in institutional legitimacy and the poor application of formal rules (Franičević, 2001) left plenty of room to head officials and public servants towards the following objective: grabbing as much as possible while they still could (Schleifer, 1997: 404). The transition confirmed political theories on the development of institutions: ${ }^{12}$ institutions are given their shape by those who are in power so that they can stay in power and funnel resources towards

\footnotetext{
${ }^{10}$ In connection with a comment attributed to George Box might be quoted: all models are wrong, but some are useful (Kennedy, 2003:81). Theil (1971: VI) wrote that models should be applied but need not be believed.

${ }^{11}$ The year 2001 is mentioned since this is the last year in which there are available GDP data in international Gheary-Kamis 1990dollars. The international dollar was created in order to increase the comparability of data from national accounts. The relative prices of a particular good in a country are equated with the weighted average price of the good in all countries (117 of them), or with the international price. This level of prices is then standardised so that the level of the USA GDP in American dollars is equivalent to that in international dollars.

${ }^{12}$ For a classification of the theory of the development of institutions, see La Port et al. (1999).
} 
themselves. Of course, the transitional countries do differ among themselves, and hence the process of rent-seeking cannot be equally powerful in all countries, which could have affected the differences in their economic performance.

Fines of econometric investigations already carried out and mentioned show that there is a statistically significant correlation between quality of governance and rate of growth and level of real per capita GDP. Here the goal is to check out these results on an EU-14 ${ }^{13}$ and 11 transition country (eight new members ${ }^{14}$ and three candidates) sample. It should be said at once that economists' debates about growth usually concern GDP long-term growth. In the case of the transition countries, however, this is concerned with short-term per capita GDP (Campos and Coricelli, 2002). Perhaps in the case of the transition countries, because of the short time series, the link between governance and business cycles should be considered, but this well be left for some future investigation. The incentives affecting the size of savings, investment and technological progress do not differ greatly according to the time period that is analysed, especially when these stimuli refer to the institutional structure.

It was only at the end of the 1990s that institutions were brought into econometric investigations of growth in the transitional countries, and then with the problems stated. When the transitional counties are in the sample, they become even more complex. ${ }^{15}$ For every investigation covering the transition countries is from the outset restricted not only because of the short time span for which data are available but also because the countries did not have the same tempo for carrying out reforms. Accordingly, these countries might have had different models of growth. As well as the standard shortcomings of indicators of quality of governance, in the transition countries the reliability of the size of GDP is also dubious, because of the very large unofficial economy.

The investigations include a quandary as to whether the dependent variable in the economic growth empirical analysis should be the rate or the level of growth. Most researchers to date have used the average rate of growth in real GDP during a period of 15 and more years as the independent variable, but in this paper, because of the brevity of the period of time observed and the great structural changes through which the transition countries went, we shall observe the per capita level of GDP and not the rate of growth. ${ }^{16}$ It is unsure whether only one equation or two should be employed for growth (one of which has investment as the dependent variable) because high growth in a short period of time can increase

\footnotetext{
${ }_{13}^{13}$ Luxembourg has an atypical value of real p.c. GDP, and it will be omitted.

14 It might be said that the new members have already completed the transition. Yet they will be considered transitional here because they entered the EU only in 2004, while the data series that we are going to use here was completed in 2001.

${ }^{15}$ Croatia itself has to date been included into only four investigations of governance and growth: Ahrens and Meurers (2000), Campos (2000), Havrylyshyn and Rooden (2003) and Beck and Laeven (2005). The first showed a greater correlation between governance and p.c. FDI than with p.c. GDP; in the second the link between the rule of law with levels and rates of growth of p.c. GDP was shown; the third indicated that the influence of institutions in the growth of the transitional countries was relatively small, while the fourth had just the opposite conclusion: institutions have had a considerable effect on the growth of the transitional countries. Most often mentioned is the work of Havrylyshyna and Rooden (2003), but there are many shortcomings to it: a) it has an index of economic freedoms as measure of institutions, and it actually includes various evaluations of trade, taxation, wages, prices, fiscal policy and so on - institutions are defined fairly inaccurately; b) the correlation between institutional indicators that were used in the growth equation is very high, which is a little suspect, for there are legal, economic and political institutions (this perhaps indicates the excessive subjectivity of the institutional indicators used); c) the authors did not take into account the effects of liberalisation, stabilisation and privatisation being different with respect to the different institutional backgrounds; d) institutional indicators relate to 1997, and they are used to measure growth from 1991 to 1998.

${ }^{16}$ Hall and Jones (1999) also urged an analysis of levels of p.c. GDP, for the rates are anyway studied because they have an impact on the levels.
} 
the demand for investment. Most often only one equation is used, and we shall act accordingly in this paper as well. Even if the extent of the effect of investment (especially foreign investment) on growth in the transition countries is questionable, the fact remains that governance will affect both totally productivity of growth factors and investment in human capital, which is often left out of the analysis.

The question arises as to which is the best way to carry out the econometric analysis. Since aggregate indicators of quality of governance for Croatia have existed only since 1995, and since the last available GDP per capita in international 1990 dollars is for 2001, an analysis of a time series is clearly not a good approach. ${ }^{17}$ Cross-country analysis for a single period is also not acceptable for all told this is a matter of 25 countries, that should very probably be divided into two groups (the EU 14 and the transitional countries) which result in too small a number of observations. Instead of that, we shall carry out a panel analysis, via a model with fixed effects, which is recommended when the units under observation are countries (Wooldridge, 2002:473), which is confirmed by the Hausman test as well. ${ }^{18}$

The initial linear regression model that we wish to evaluate is:

$$
\log y_{i t}=\alpha_{i t}+\beta_{i} x^{\prime}+\varepsilon_{i t},
$$

for the units observed (the countries) $i=1,2 \ldots N$, in which $N=25$, and the time period is $t=1,2 \ldots, T$. Since a fixed effects model has been selected, $\alpha$ will differ for each country of the sample, or $\alpha_{i t}=\alpha_{i}$; this parameter is a constant specific for a given country. Panel analysis gives the possibility of choosing whether $\beta$ will be assessed for each country separately or for the whole sample, here we shall choose a $\beta$ in common because of the greater credibility of the results (a larger number of observations when all the countries are observed), with the proviso that $\beta$ will also be assessed for two sub-groups of countries: the EU 14 and the 11 transition countries. Meanwhile, $X_{i t}$ is the k-dimensional transposed vector that will represent the indicators of the rule of law and the quality of the public administration, and $\varepsilon_{i t}$ is an error term. ${ }^{19}$ We shall evaluate the parameters with the weighted least squares method (GLS), and in order to remove the effect of the constant factors on the dependent variable, each variable will be differenced through time (Wooldridge, 2002). The difference is nothing but a change in the value of the variable $(\Delta)$ between the two periods.

The most important limiting element of this investigation is that governance is considered to be an exogenous variable, that is, the feedback effect of economic growth on the quality of governance will not

\footnotetext{
17 This work will use aggregate indicators because they are founded on several sources and better picture the real state of things. For example, it is a bit strange that the indicator of the protection of property rights of the Heritage Foundation (2005) for Croatia did not change at all between 1997 and 2005. The same holds true for the administrative hurdles in starting companies.

${ }^{18}$ The fixed effects model partially settles the problem of heterogeneity of parameters, but it should be borne in mind that this problem is characteristic of all social research. A panel analysis gives a greater insight into the dynamic effects of institutional changes, which can be large even in the short run; this is not possible with cross-country analyses, for averages for a certain longer period of time are used. The advantage here is that it is better for solving problems of omitted variables that change inconsiderably over time (such as, for example, geographical position), but it does not solve the issue of business cycles within the observed period of time. In previous panel analyses data are mainly grouped into five-year averages (Islam, 1995), which is supposed to suit business cycles better, but this seems dubious. Unfortunately, in this paper, the period of observation is too short for grouping into averages longer than two years (1995=/96, 1997/98, 1999/00 and 2001/02). Grouping will be carried out primarily because the available aggregate indicators of quality of governance relate to the two-year average. For the last group, p.c. GDP figures are available only for 2001.

${ }_{19}$ Since the correlation among various indicators of governance quality is very high, we shall not put them into the same equation in order to avoid the problem of multicolinearity. Here $k$ indicates a number of independent variables.
} 
be taken into consideration. Although it is hard to define the size of this feedback effect, for the moment available estimates suggest that it is minimal in the short term (Kaufmann, Kraay and Mastruzzi, 2005). ${ }^{20}$ Since institutions impact growth, and growth impacts institutions, there must be some third factors that have an effect on both growth and institutions, for the discovery of which research work from psychologists and sociologists is required. ${ }^{21}$ In the sequel we give an analysis of the relation between the rule of law and the quality of governance and economic growth.

\subsection{The rule of law and economic growth}

The definition of the rule of law in this paper focuses on the role of the judiciary. It is double: above all it is the protection of the rights and liberties of the citizens that ensure them equality before the law, and the second part is that it has to supervise the legislative and executive arms of government. If the courts do not protect rights of property, do not enforce contracts and do not resolve disputes in good time then the motivation for investment and innovation is reduced, that is, the incentives for productive activities are lowered, and those for rent-seeking are enlarged. Similarly, if the courts are corrupt, this will indicate that citizens are not all equal before the law, for equity in the sense of "to each his deserts" is confounded. A justice system that is corrupt or politically dependent can facilitate high-level corruption and weaken reforms, affecting economic growth (Feld and Voigt, 2003). Failure to respect the rule of law brings about a fall in the confidence in justice, and respect for the justice system, in turn, can be correlated with the level of investment (World Bank, 1997:36)

Data from the research of Kaufmann, Kraay and Mastruzzi (2003) contain aggregated indicators of the rule of law. They are used to estimate how much the rules of society are respected, and include (citizens', investors' and analysts') perceptions of the dissemination of crime, the effectiveness of the courts and the enforcement of contracts. They range from -2.5 to +2.5 , a large number indicating better performance. ${ }^{22}$ The shortcoming of this indicator is that it contains relatively large measurement errors (as compared with the range of the indicator) for it is based on perceptions and because the individual indices that were employed in the aggregation did not perhaps characterize very well the concept that it was wished to quantify. The problem here is that a large number of sources was employed, in which in various ways the working of the rule of law was evaluated, and no very strict selection was made at the same time. It is not good to apply it to the monitoring of global trends in institutional development because during the aggregation the starting point was that the mean value of a global indicator in each period is the same, but it can show very well the relative position of a country as compared with the

\footnotetext{
${ }^{20}$ Works in which a strong influence of governance on p.c. GDP are adduced are for example: Hall and Jones (1999), Kaufmann and Kraay (2002), Acemoglu et al. (2004), Rodrik et al. (2004). For an opposite opinion, see Sachs et al. (2004).

${ }^{21}$ Probably some reader might hold its simplicity against the model used in this work, primarily because of the exclusion of control variables that relate to economic policy. However, Acemoglu et al. (2003) have shown that countries with bad macroeconomic policy (high inflation, high budgetary deficits, a misaligned exchange rate) have at the same time weak institutions (lack of protection for the rights of investors, widespread corruption, an insufficiently controlled political elite). In other words, macroeconomic problems are a reflection of institutional problems. Unfortunately, the issue of quality of governance and economic growth is too complex to be shown with an elegant theoretical model, but at the same time there are too many obstacles for it to be based only on econometrics. For this reason, in this paper, there is an effort to approach the relation between quality of governance and economic growth from several sides, which can leave an impression of superficiality for the space for analysis is restricted by the length requirements for the article.
} 
global average (of about 200 countries), even over time. The Croatian indicator is much lower than that for the EU 15; Croatia also lags behind the new members, and is in front only of Bulgaria and Romania. ${ }^{23}$ The only positive thing is that this difference is reducing.

With the use of this indicator for the rule of law and Maddison's data about real per capita GDP in constant 1990 international dollars (Maddison, 2005) the following statistically significant results at the $1 \%$ level are obtained: if the indicator of the rule of law is greater than 1 , then $\Delta \log y$ will be increased by 0.067982 , or real per capita GDP will go up by $7.03 \%$ [( $\left.\left.e^{0,067982}-1\right)^{\star} 100\right]$, which goes for 25 countries of the sample (adjusted $R^{2}=0.83$ ). For the EU 14 growth is $4.28 \%$ (adjusted $R^{2}=0.91$ ); for the 11 transitional countries it is $15.04 \%$ (adjusted $R^{2}=0.80$ ). ${ }^{24}$ Since the growth of indicators of the rule of law by 1 sounds rather abstract, taking the example of Croatia it would mean attaining the level of the rule of law that pertains in, for example, Spain, which would in turn mean a rise in the growth of real GDP per capita by $15.04 \%$. Such percentages have to be used with great circumspection because of the numerous constraints, but two things are very certainly visible from them. Firstly, countries can benefit by improving the quality of governance, and in a short period at that; secondly, the effect of the quality of governance on growth is greater in the transition countries than it is in the old member states of the EU.

\subsection{Quality of public administration and economic growth}

In the context of quality of the public administration or civil service we shall consider the relation between corruption-cum-the degree of bureaucratisation and economic growth.

There is increasing empirical evidence that corruption has a negative impact on economic growth; countries with widespread corruption have lower levels and rates of GDP growth (Mauro, 1995; Knack and Keefer, 1995; Brunetti, Kisunko and Weder, 1997). Possible channels through which corruption has its effect on the reduction of economic growth are lower foreign and domestic investment ${ }^{25}$, the targeting of government spending towards less effective projects that enable the more frequent pocketing of bribes, i.e., the reduction of the productivity of public investment, but not the proportion of GDP that they constitute (Tanzi and Davoodi, 1997; Rose-Ackerman, 2002). Even when corruption and economic growth do coexist, corruption brings in costs and distortions in the allocation of resources ${ }^{26}$ In corrupt

\footnotetext{
${ }^{22}$ Values of from -2.5 to 2.5 are weighted average scores for each country that have been rescaled into common units. The weightings are proportional to the precision of the data of the sources used, and the precision depends on how strong the correlation between the individual sources is.

${ }^{23}$ In this work the last indicator for the rule of law used is information for 2001/2002, for the available p.c. GDP in international dollars sequence from 1990 ended in 2001. However, there is an item for 2003/2004, according to which the score for the rule of law in Croatia is a little worse than two years earlier (Kaufmann et al., 2005). The paper does not quote the table with the figures for all of the countries from the sample, for a graphic presentation is to be found in Badjun (2004).

${ }^{24}$ Tables containing constants for each country and other econometric results are given in the Annex (Tables I, II and III).

${ }^{25}$ Private investment in conditions of widespread corruption is lower, because this works as a kind of tax upon investors, or as an extra cost, and also as insecurity.

${ }^{26}$ Italy can be adduced as an example, that is, the differences between the north and the south. Italy is often given as an example of a country in which corruption and growth manage to coexist, but sight is lost of what Italian p.c. GDP might be if there were less corruption. It is possible that corruption in Italy is internalised, in the sense that bribes are felt as just another tax, and hence the uncertainties and risks to investors are lower than in a country in which corruption is equally widespread, but in which the outcomes and effects of the payment of bribes are less certain. This, of course, is mere speculation, which would need to be verified.
} 
states, the incentives that exist will tend to induce the most talented individuals to activities maximising the benefits from corruption, which can also have negative consequences to growth.

When corruption is at issue, it is difficult to make comparative analyses based on firm evidence because the number of cases of corruption that actually come before the courts can tell more about the justice system than about the real spread of corruption. Instead of that, use is made of various indices showing the perception of corruption. Among the aggregate indicators of World Bank researchers (Kaufmann, Kraay and Mastruzzi, 2003) there is an indicator of the spread of corruption the range of which also moves between -2.5 and +2.5 . According to this indicator, Croatia lags considerably behind the EU 15 and the new members, its result being better only than those of Bulgaria and Romania. ${ }^{27}$

The procedure for econometric analysis is identical to that in the case of the rule of law, except that the dependent variable is set as the indicator of the extent of corruption. If the value of this variable increases by 1 , then for the 25 countries, real GDP will rise by $0.69 \%$ (adjusted $R^{2}=0.76$ ); for the EU 14 no statistically significant correlation has been established, and in the case of the transition countries the rise will be $7.31 \%$ (adjusted $R^{2}=0.85$ ) ${ }^{28}$ In the case of Croatia, the situation would be as follows: if perceptions concerning corruption changed enough for them to be similar to those in Portugal, real per capita GDP would rise by about $7 \%$. From these results it can be assumed that the impact of corruption on per capita GDP in the transition countries is greater than in the EU 14. It is interesting also that the results of the authors of previous investigations are confirmed, according to which the effect of the rule of law on per capita GDP is greater than the impact of corruption. This can be explained by corruption deriving from failure to respect the rule of law, where the rule of law is a more powerful factor impacting economic growth. The second explanation might be that investors simply perceive failure to respect the rule of law as a greater obstacle than corruption.

It is possible to observe indirectly through corruption the correlation between degree of bureaucratisation and economic growth. ${ }^{29}$ For complicated and lengthy administrative procedures form part of the growth of important disincentives for potential investors, particularly foreign investors. A high degree of bureaucratisation may drive away investors irrespective of the existence of generous incentives and sound legal security. Since time is money, investors will be ready to pay to avoid any delays during entry into the market or during business operations. ${ }^{30}$ As against this, the existence of rules and various procedures that the potential investor might have to go through gives the civil servant a monopoly power - they can deny the issue of a license or delay its production for several months (Tanzi, 1998:566). This is how they are able to use their power for the demand for bribes. Bribes can also have an influence on the order in which an investor will obtained certain authorisations. All of this has a demotivating effect on start-ups (and new firms can generate new investment) and can push the activity into the unofficial economy.

\footnotetext{
${ }^{27}$ As with the rule of law, indicators for the spread of corruption from Kaufmann et al. (2005) deteriorated in the period from $2001 / 2002$ to $2003 / 2004$.

${ }^{28}$ Tables with results of econometric analysis are given in the Annex (Tables IV, V and VI).

${ }^{29}$ Unluckily, there are no appropriate data for a panel analysis of the direct relation between bureaucratisation and economic growth.

30 Once it was considered that corruption might even favour development, because it speeds up certain procedures (Leff, 1964), but acceleration of procedures is not a good enough argument for the toleration of corruption.
} 
When an enterprise has a plan and wants to put it into operation, it will first of all come up short against the administrative and legal procedures that it has to go through to be registered, i.e., to set up the company. The World Bank has created its database called Doing Business (2005a) in which there is information about the existing procedures for incorporating a company, as well as information about the minimum period of waiting and the costs of incorporation. ${ }^{31}$ Table 1 would suggest that the procedure for registering an enterprise in Croatia is not very long, complicated or expensive as compared with the EU 14 average, but these data do not tell very much about the real situation because they do not contain the bureaucratic delays in the civil service, the hold-ups in the commercial courts, or the time necessary to get hooked up to the utility infrastructure or the time that an entrepreneur will lose while he or she tries to find information about how to start the firm. Even without the bureaucratic delays, 49 days seems a lot compared with the five in Denmark, and 12 procedures excessive as against the three in Sweden. Twelve procedures is at the same time more than in the other transition countries. From Table 1 it can be seen that the less developed EU countries (Spain, Portugal and Greece) also have longer procedures for founding companies. It is interesting to see that the indicators for Romania are more positive than those for Croatian and Bulgaria, even than for the EU average. Perhaps this is the consequence of the introduction of the "tacit approval procedure" in May 2003; if the public administration in Romania does not give a firm an answer to an application for some permission in a period of 30 days, it is deemed that the authorisation has been issued (EBRD, 2003:181).

Table 1 Starting a business and the corruption perception index (CPI)

\begin{tabular}{|l|r|r|r|r|}
\hline Country & Number of procedures & Number of days & $\begin{array}{r}\text { Cost in terms of \% GNI } \\
\text { per capita }\end{array}$ & $\mathbf{C P I}_{\mathbf{2 0 0 5}}$ \\
\hline Austria & 9 & 29 & 5.7 & 8.7 \\
\hline Belgium & 4 & 34 & 11.1 & 7.0 \\
\hline Denmark & 3 & 5 & 0 & 9.5 \\
\hline Finland & 3 & 14 & 1.2 & 9.6 \\
\hline France & 7 & 8 & 1.2 & 7.5 \\
\hline Germany & 9 & 24 & 4.7 & 8.2 \\
\hline Greece & 13 & 49 & 24.6 & 4.3 \\
\hline Holland & 7 & 11 & 13.0 & 8.6 \\
\hline Ireland & 4 & 24 & 5.3 & 7.4 \\
\hline Italy & 9 & 13 & 15.7 & 5.0 \\
\hline Portugal & 11 & 54 & 13.4 & 6.5 \\
\hline Spain & 10 & 47 & 16.5 & 7.0 \\
\hline Sweden & 3 & 16 & 0.7 & 9.2 \\
\hline United Kingdom & 6 & 18 & 0.7 & 8.6 \\
\hline EU-14 average & $\mathbf{7}$ & $\mathbf{2 5}$ & $\mathbf{8 . 1}$ & $\mathbf{7 . 7}$ \\
\hline Bulgaria & 11 & 32 & 9.6 & 4.0 \\
\hline Croatia & $\mathbf{1 2}$ & $\mathbf{4 9}$ & $\mathbf{1 3 . 4}$ & $\mathbf{3 . 4}$ \\
\hline Czech Republic & 10 & 40 & 9.5 & 4.3 \\
\hline
\end{tabular}

\footnotetext{
${ }^{31}$ Procedures include the applications that relate to future taxation, labour force, safety at work, satisfactory ecological criteria and all the other conditions that a firm has to satisfy before starting to operate lawfully. A firm that an entrepreneur wishes to firm is standardised and so there are those of up to 50 employees, initial capital that is 10 times greater than the p.c. GDP of the economy, 100\% domestic owned, will operated in the most populated area, will deal with production or commerce, will not receive any special privileges or tax breaks and so on. Certain assumptions that relate to the standardised firm reduce the complexity of starting a company, for it is certainly not the same to start a business in Zagreb or in some small city. The methodology of the research is developed in Djankov et al. (2002).
} 


\begin{tabular}{|l|r|r|r|r|}
\hline Estonia & 6 & 35 & 6.2 & 6.4 \\
\hline Hungary & 6 & 38 & 22.4 & 4.2 \\
\hline Latvia & 7 & 18 & 3.3 & 4.2 \\
\hline Lithuania & 8 & 26 & 22.2 & 4.8 \\
\hline Poland & 10 & 31 & 5.3 & 3.4 \\
\hline Romania & 5 & 11 & 5.1 & 3.0 \\
\hline Slovakia & 9 & 25 & 10.1 & 4.3 \\
\hline Slovenia & 9 & 60 & 10.1 & 6.1 \\
\hline $\begin{array}{l}\text { Eleven transition } \\
\text { countries average }\end{array}$ & $\mathbf{8}$ & 33 & $\mathbf{3 3}$ & $\mathbf{4}$ \\
\hline
\end{tabular}

Note: World Bank data relate to the beginning of 2005. The CPI ranges from 0 (total corruption) to 10 (no corruption at all). The results of the $\mathrm{CPI}$ are drawn up on the basis of a total of 18 investigations carried out by independent foreign institutions, and the respondents were mainly business people and analysts.

Source: World Bank (2005b) and Transparency International Croatia (2005)

The research of Djankov et al. (2002) had already shown from a sample of 85 countries in 1999 that in countries in which it is harder to start an enterprise (measured by number of procedures, minimum amount of time required for incorporation and registration as well as the costs of starting) corruption is more widespread and the unofficial economy is larger. It was also shown that the administrative hurdles are fewer in countries in which there are greater constraints on executive government and greater political rights, even when per capita GDP is included as independent variable. ${ }^{32}$ Their results show that the purpose of the hurdles is to extract rent: those who have the greatest benefit from them are officials and lower grade civil servants. Countries that have fewer political rights and less control over government will thus have a greater number of administrative hoops to jump through.

This investigation relates to data from 1999, and when the data from 2005 are applied, then the simple linear correlation coefficient between number of procedures and the $\mathrm{CPI}_{2005}$ indicator (Corruption Perception Index of Transparency International, Table 1) comes to -0.71 for the EU-14 and -0.28 for the transition countries, and overall it is -0.57 . The first indicator reveals a strong correlation, the second a weak one, and the third a medium strength correlation, while the negative sign indicates the trend of the variable in the opposite direction: a small number of procedures is correlated with a larger CPI index, which shows a small perception of corruption. When the relation between number of days and $\mathrm{CPI}_{2005}$ is considered, then the coefficient of correlation for the EU-14 comes to -0.57 , and for the transition countries the prefix is positive and comes to 0.48 . The positive sign means that in the transitional countries a larger number of days is correlated with a smaller perception of corruption. The coefficients for the EU 14 bear out the previous results: a larger number of days and procedures necessary to start a firm is linked with greater corruption. Why does this not hold true for the transition countries as well?

Probably part of the answer to this question derives from the fact that the number of days indicator relates to the minimum number of days required to start a firm, and not the real number of days. Inclusion of bureaucratic delays would certainly change the results, but unfortunately we are not yet able to check this out since there are no suitable data. The second reason is that in the transition countries bribes are perhaps not so much necessary for the acceleration of the incorporation and registration procedure as for winning certain advantages during incorporation and for certain investors to be put into

\footnotetext{
${ }^{32}$ In this they wanted to show that countries do not have fewer administrative obstacles because they are rich and have more developed markets and less need for regulation.
} 
an unjustifiably more favourable position. The third hypothesis is that the results would be different if the time necessary for entry into the land register were taken into account, for this is not included in the registration process; the same would probably also hold if the time necessary for infrastructure connections to be obtained.

What can be concluded from the econometric analyses carried out in this paper? The institutional shortcomings have had an effect on the current level of real GDP in Croatia, and also faster and more effective changes in governance would certainly contribute to economic growth in the future. This particularly holds good for the reform of justice and the civil service, for fighting corruption as well as for strengthening the democratic mechanisms for controlling those in whom political power is vested. Such a conclusion might seem to be insufficiently founded, because, primarily, of the many econometric limitations, particularly those related to governance as an exogenous variable. However, most of the research carried out to date on the topic of institutions and growth shows that the influence from institutions on growth is stronger than the other way round. So that everything should not be left at possibly unconvincing econometric evidence, on the theory of growth that is not well enough worked out, on dubious facts of the transition and the opinions of two scientists from the area of economic history (Jones and North), in the sequel we shall give a brief commentary on the changes of the quality of governance in Croatia. This is the last attempt to providing convincing arguments that institutions have had and still have an important role in economic growth in Croatia, this time, however, with the accent placed on those by whom they are created.

\section{CHANGES IN THE QUALITY OF GOVERNANCE IN CROATIA}

The problems of the Croatian justice system and the public administration have already been identified (see for example Ott, 2004) and are known to those in power (see for example Government of RC, 2003). Clearly, in terms of an environment providing incentives for investment into physical and human capital and into innovations, Croatia is well behind the countries of the EU, or in other words, it is approximately in the same group as Bulgaria and Romania. In this paper, this can be seen from the indicators for the rule of law, indicators of the diffusion of corruption and the administrative hurdles to the starting of a corporate enterprise. ${ }^{33}$ What is less discussed, however, is the speed with which changes in the quality of governance in Croatia are arrived at and the nature of these changes.

Very likely the first objection that the informed reader might make relates to administrative obstacles and the question expected would be: Well, what about hitro.hr? ${ }^{34}$ The first improvements or simplifications in the incorporation and registration procedure in Croatia started happening as late as 2001. At that time a special working group for the obviation of administrative obstacles was set up; however, the results of its work were practically imperceptible to investors. In 2002 the Government committed itself to making the registration procedure last not more than 30 days, but this measure was stillborn because it would have been necessary previously to have carried out the computerisation of the commercial courts and to have put the land registers in order. In 2003, the Government announced the formation of a one-stop-shop,

\footnotetext{
${ }^{33}$ For a detailed comparison of Croatia with the EU average and with Bulgaria and Romania (over time), on the basis of different indicators of governance quality, see Badjun (2004).

${ }^{34}$ This is the one-stop-shop, via which four steps would have to be taken to start a limited liability company, the whole procedure lasting 15 days.
} 
which was put into practice only in May 2005 (hitro.hr). In the meantime, the problem of the overloading of the commercial courts has not been settled, and so the question necessarily arises as to the effectiveness of this new service. Furthermore, it will be available only in the large cities, and the problems that exist in smaller and outlying towns will remain, and it is actually local civil servants that improvise too much, that is, they have too much space of the free interpretation of the regulations (FIAS, 2001).

Corruption is intimately connected with the ability of civil servants to act according to discretionary principles. Up to 2000, those in whom power was vested in Croatia did not undertake any active measures for the suppression of corruption. Since that time, the National Programme for the Fight Against Corruption (OG 34/02) has been adopted, the Office for the Suppression of Corruption and Organised Crime - known as USKOK has been founded (OG 88/01), the Prevention of Conflict of Interest in the Performance of Public Office Law has been passed (OG 163/03), the Right to Access to Information Law has been passed (OG 172/03) and anti-corruption conventions have been ratified. The existence of these necessary laws and the involvement of the international community stirs optimism about the suppression of corruption in Croatia. However, very few of the indictments filed for corruption have actually ended in guilty verdicts, and the number of convictions attended by terms of imprisonment as a result of the work of USKOK is practically negligible. ${ }^{35}$ And it is certainly widely at odds with public perception of the extent of corruption in the country: $55 \%$ of respondents think it very widely developed, $34 \%$ developed (Transparency International Croatia, 2005). Also indicative is the Corruption Perception Index (TI, 2005) which has been constantly on the decline since 2001, which means that business people and analysts perceive no positive movements in the fight against corruption in Croatia. ${ }^{36}$

Thus, a large part of the problem lies in the application of the actual laws. For instance, although there is a Right to Access Information law, there are very frequent complaints from journalists that civil servants thwart any access to this information. ${ }^{37}$ However, there is also still room for new laws (there is no, for instance, financing of political parties $\operatorname{law}^{38}$ ) and sometimes the substance of the current laws is quite dubious. Thus the Prevention of Conflict of Interests Law passed in 2003 has already undergone two revisions, in which the circle of relevant officials has been enlarged, the problem of appointing officials to supervisory boards of companies has remained, and an article has been introduced that says "In the evaluation of the existence of a conflict of interest, special account will be taken of the nature of the office that the official holds"; nothing can justify the existence of such an article. A second example is the Law concerning the Procedure for the Transference of Government (OG 94/04), which is not precise enough

\footnotetext{
${ }^{35}$ USKOK on the whole deals with procedures against ordinary members of the public for some negligible act of bribery. Its applications for investigations to be opened against well-known political and judicial officials were rejected by the Supreme Court. So far experience shows that USKOK works in an inimical atmosphere and in a surrounding in which it cannot operate (Kregar, 2004). Its inefficiency should be ascribed not so much to its weakness as to the power of the individuals and interest groups against which it is fighting.

${ }^{36}$ It is interesting to see that the annual rates of growth of p.c. GDP for Croatia from 2002 to 2004 fell from 5 to 4 and $2 \%$ (World Bank, 2005). At the same time the CPI for Romania improved, and the rates of growth from 2002 to 2004 were 6,5 and $8 \%$. These numbers suggest that the results of econometric analysis carried out in this work would probably not change substantially even if data for p.c. GDP in international 1990 dollars did exist up to 2004.

37 Transparency International Croatia (2005a) send 200 questionnaires to governmental bodies during August and September with a response rate of $56 \%$, which is cause for concern for the Law had been in force since October 2003.

${ }^{38}$ A possible solution is the reworking of the existing Political Parties Law (Official Gazette 76/93).
} 
and does not cover the local level, thus exacerbating the already high degree of politicisation of the Croatian public administration (Kopric, 2001).

It is hard to say whether in Croatia it is senior or lower level public servants that represent a greater problem of corruption; however, probably the first group has a more destructive effect on economic growth. This concerns the procedures of individuals, groups and firms that, working for their own advantage, influence the framing of laws, regulations, verdicts and governmental measures, and in so doing provide, in a very untransparent way, private benefits for the officials who help them. From the frequent changes in the legislative background it might be concluded that interest groups are very strong in Croatia and have a powerful influence on the decisions made by the politically powerful. ${ }^{39}$ But the likelihood of there being such behaviour is greater in countries in which economic power is concentrated, in which the formal channels of political influence are undeveloped and in which social interests that would be opposed to such behaviour are weak, and all this holds good for Croatia. As for an integrated strategy for reform of the civil service in Croatia, it is enough to say that it does not yet exist.

All that remains is a glance at the reforms of the Croatian justice system, but before that it would be worthwhile quoting the views of members of the public and of investors. According to research into social capital in 1995, about $42 \%$ of people polled in Croatia had a low degree of trust in the institutions of the justice system, and 7\% had absolutely no trust at all (Stulhofer, 2001:29). By 1999, these figures had risen to 50 and 19\%. Apart from that, Transparency International Croatia (2005) showed that justice was the second priority area for the suppression of corruption. World Bank research, BEEPS ${ }^{40}(2002)$ that tested the views of entrepreneurs showed that the Croatian courts, in terms of corruption, speed of handling cases, and impartiality (or equity) were in the group of the worst-ranked systems considered in the work.

It is interesting that in 2002, 2003 and up to May 2004, there was no single case to do with corruption in the judicial system before the State Judicial Council (known as DSV) (Grcar, 2004). Effective control of judges and court clerks still does not exist; the assessment of judges by the DSV is still just words on paper. Disciplinary procedures are seldom applied to officers of the court, and the penalties handed down have been too few and too symbolic to work as a deterrent. As for the public perception of the politicisation of the Croatian courts, the problems to a great extent also derive from the DSV and the hiring system (for more on this see in Uzelac, 2001). For example, one of the criteria for the choice of judges is "demonstrated work capacities", which leaves plenty of space for manipulation. In 1999, a centre for the professional training of judges and other officers of the court was founded, but only in 2003 did it start working, and then only partially. It is laudatory that the electronic processing of the land registers is under way, but this project could have started much earlier. The strategy for the reform of the justice system was accepted only in 2002, and the operational plan was adopted in 2003.

Unfortunately, reforms of the justice system and civil service in Croatia are only half-way, and the will to carry them through is questionable, which can be seen from the absence of any clear vision concerning

\footnotetext{
${ }^{39}$ This is borne out by WB research (World Bank, 2004).

40 The Business Environment and Enterprise Survey. In 2002, research was carried out in 23 countries with a sample of 4,000 firms.
} 
reform. ${ }^{41}$ Often problems are "handled" only by passing new laws and/or adopting new strategies, concomitantly with the neglect of the fact that they are useless if they are not implemented. Then the laws are almost always passed in a hurry, in the urgent procedure, as it is called, and then according to the priorities of politicians who endeavour to give the impression that they are active (Schonfelder, 2004:12). Since changes in statute are frequent, this imparts additional instability to the operations of enterprises.

The media are able to speed up reform processes in many political systems, but in situations in which officials, during for example the disclosure of cases of corruption, which create a great deal of public support for reform, need additional planning and consultations, the process of change will be halted once more. An extra problem is that according to freedom of the media indicators, Croatia lags behind the countries considered here (Freedom House, 2005) and that until 2000 it was considered an only partially free country - according to the respect accorded to political rights and civil liberties (Freedom House, 2005a). Democracy in Croatia is still not well enough developed to be a powerful mechanism for the control of the people in power. ${ }^{42}$

Institutions, of course, do not always have to change for the better, on the contrary, institutional hardening of the arteries can occur for reasons of political opportunism, but it is a mitigating circumstance that most of the transition countries were motivated by expected accession to the EU to carry out positive changes of institutions and increase the legitimacy of reforms. It is easy to arrive at institutional change when those who have the most to gain from the existing are forced to accept the new institutions, which happens on EU accession. Increased competition among candidate countries (now member countries) reduced the gain from the status quo and the possibilities for rent-seeking were reduced, that is, under pressure from international organisations and their own constituents, those in power had to prefer a policy that facilitated the accomplishment of the fundamental goal - membership in the EU (Orenstein, 2001:131).

What is common to Croatia, Bulgaria and Romania is that they had governments that did not from the very beginning of the nineties act pro-Europeanly, with the proviso of course that Croatia was also specific because of the war. Because of the delay in starting the association process and the postponement of the beginnings of negotiations, Croatia was in an thankless situation because even the exogenous factor of the EU began to lose its influence. Problems can arise precisely when the inhabitants of a given country think that the institutions of the EU do not suit them, and they will thus not persist (Rodrik, 2003). Although negotiations have begun, it is not known how long they will go on and they can even be suspended. It is positive that the EU, to do with Croatia, is particularly insisting on the reform of the courts and the public administration, and this should speed up the exit from the bad institutional imbalance in which Croatia finds itself and contribute to economic growth.

\footnotetext{
${ }^{41}$ From 2002 to 2004 Croatia took only $10 \%$ of the resources that the WB had earmarked for it for the reform of the courts.

${ }^{42}$ Rivera-Batiz (2002) shows that democracy affects economic growth by improving governance. He measured the quality of governance (as dependent variable) as indicator that had been constructed by Hall and Jones (1999) and evaluated democracy by indicators for political rights of the organisation Freedom House. He also showed that the respect for political rights reduced corruption, hence stimulating innovation, increasing the rate of return on capital and the growth rate in a state of equilibrium.
} 
What is worth bearing in mind, however banal it might seem, is that the people actually chose those in power in Croatia to be their own representatives. The question arises as to what changes there should be in the whole of Croatian society so that one small (elected) portion of it would on its own initiative create good formal institutions. The exclusion of informal institutions from the analysis, as has been done in this paper, will probably not bring us any closer to finding an answer.

\section{CONCLUSION}

This paper has shown that it is exceptionally important to bring the quality of governance explicitly into the debate on economic growth in Croatia. Evidence for this has been found in the new theory of economic growth, in existing empirical investigations into growth, an econometric (panel) analysis of governance and economic growth in a sample of EU countries and three candidate countries (including Croatia and an analysis of the speed of changes in the quality of the Croatian courts and civil service, as well as by a consideration of the nature of these changes.

If in some country there are no effective control mechanisms over the work of government officials and lower members of the civil service (a low level of the rule of law, inadequate media freedom, failure to respect political rights and civil liberties), if politicisation and corruption are widely diffused in the civil service and the courts, and if the degree of bureaucratisation is high, then this shows that the state is using power more negatively for the shaping of the institutional environment. These criteria hold true for Croatia, and it follows that those in whom political power is vested in Croatia are more concentrated on rent-seeking than the EU average. Institutional shortcomings have impacted the current level of real per capita GDP in Croatia, and more rapid and effective reforms of the judicial system and the public administration, as well as the suppression of corruption and beefing up democracy would have a positive effect on future economic growth. Since the likelihood of some endogenous revolution in Croatia is very small, the expected entry into the EU is an important factor that should help to bring about positive changes in the quality of governance. This paper has in no way wanted to say that economic policy is unimportant, but that there are priorities, the most important of which is the rule of law. This is not a new claim, and it has existed at least since Adam Smith, but it occasionally tends to be overlooked.

Science is still only at the beginning of incorporating institutions into the theory of growth. Although in this paper we have endeavoured to contribute to the debate on the link between governance and economic growth, there are many issues of an empirical and theoretical still remaining to be investigated. The main unsettled question is how productive institutions (i.e. favouring growth) come into existence, or what hidden variables there are behind them. How should one react to the fact that institutions crated a century ago can affect the current level of GDP? What is the interaction between formal and informal institutions? What leads to the point at which governance sets out on a new course? How are good rulers created? How can balance be created within, as distinct from order being forced on the society from outside? As always happens, the most interesting questions remain unanswered and are left for future research. Perhaps indeed a great deal in economic growth does depend on luck; but researchers find this hard to accept. 


\section{REFERENCES}

Acemoglu, D. [et al.], 2003. "Institutional causes, macroeconomic symptoms: volatility, crises and growth". Journal of Monetary Economics, 50, 49-123.

Acemoglu, D., Johnson, S. and Robinson, J., 2004. "Institutions as the Fundamental Cause of Longrun Growth". National Bureau of Economic Research Working Paper, No. 10481.

Ahrens, J. and Meurers, M., 2000. "Institutions, Governance, and Economic Performance in PostSocialist Countries: A Conceptual and Empirical Approach". $4^{\text {th }}$ International Conference "Institutions in Transition", 23 - 24 lipanj, Portorož, Slovenija

Bađun, M., 2004. "Governance i javna uprava u kontekstu pridruživanja Hrvatske Europskoj uniji" u K. Ott, ur. Pridruživanje Hrvatske Europskoj uniji - izazovi institucionalnih prilagodbi. Zagreb: Institut za javne financije : Zaklada Friedrich Ebert, Zagreb, 125-153.

Beck, T. and Laeven, L., 2005. "Institution Building and Growth in Transition Economies". World Bank, Policy Research Working Paper, No. 3657.

Brunetti, A., Kisunko, W. and Weder, B., 1997. "Institutional Obstacles for Doing Business". World Bank Working Paper, No. 1759.

Campos, N. F. and Coricelli, F., 2002. "Growth in Transition: What We Know, What We Don't, and What We Should". William Davidson Institute Working Paper, No. 470.

Campos, N. F., 2000. "Context is Everything: Measuring Institutional Change in Transition Economies". World Bank Working Paper, No. 2269.

Djankov, S. [et al.], 2002. "The Regulation of Entry". The Quarterly Journal of Economics, 117 (1), 1-37.

EBRD, 2003. Integration and Regional Cooperation. Transition Report 2003. Amsterdam: European Bank for Reconstruction and Development.

Evans, P. and Rauch, J., 1999. "Bureaucracy and Growth: A Cross National Analysis of the Effects of "Weberian" State Structures on Economic Growth". American Sociological Review, 64 (5), 748-765.

Feld, L. P. and Voigt, S., 2003. "Economic Growth and Judicial Independence: Cross Country Evidence Using A New Set of Indicators". CESifo Working Paper, No. 906.

FIAS, 2001. "Hrvatska: administrativne prepreke stranim ulaganjima" [online]. Foreign Investment Advisory Service. Dostupno na: [http://www.worldbank.hr/eca/croatia.nsf/ECADocByUnid/F870F366649A9FFAC1256B8B00440410/\$F ILE/fias-croatian.pdf].

Franičević, V., 2001. "The Postsocialist States in Southeast Europe: Challenges and Dilemmas". Politička misao, 38 (5), 62-86.

Freedom House, 2005. Press Freedom Survey [online]. Available from: [http://freedomhouse.org/research/ratings.XLS].

Freedom House, 2005a. Freedom in the World [online]. Available from: [http://freedomhouse.org/research/freeworld/FHSCORES.xls].

Glaeser, E. L. [et al.], 2004. "Do Institutions Cause Growth?". National Bureau of Economic Research Working Paper, No.10568.

Grčar, I., 2004. "DSV nije pokrenuo ni jedan postupak zbog korupcije sudaca". Dnevnik, 5.4.2004., str. 8

Hall, R. and Jones, C. I., 1999. "Why do some countries produce so much output per worker than others?". Quarterly Journal of Economics, 114 (1), 83-117.

Havrylyshyn, O. and van Rooden, R., 2003. "Institutions Matter in Transition, but so do Policies". Comparative Economic Studies, 55, 2-24.

Heritage Foundation, 2005. Index of Economic Freedom [online]. Available from: [ttp://www.heritage.org/research/features/index/pastScores.xls].

Islam, N., 1995. "Growth Empirics: A Panel Data Approach". The Quarterly Journal of Economics, 110(4), 1127-1170.

Jones, E. L., 2003. Ekonomski rast u svjetskoj povijesti. Zagreb: Politička kultura. 
Kasper, W. and Streit, M. E., 1998. Institutional Economics. Cheltenham: Edward Elgar.

Kaufmann, D. and Kraay, A., 2002. "Growth Without Governance" [online]. World Bank Working Paper, No. 2928. Available from: [http://www.worldbank.org/wbi/governance/pdf/growthgov.pdf].

Kaufmann, D., Kraay, A. and Mastruzzi, M., 2003. "Governance Matters III: Governance Indicators for 1996-2002" [online]. Washington: The World Bank: draft for comment. Available from: [http://www.worldbank.org/wbi/governance/pdf/govmatters3.pdf].

Kaufmann, D., Kraay, A. and Mastruzzi, M., 2005. "Governance Matters IV: Governance Indicators for 1996-2004" [online]. Washington: The World Bank: draft for comment. Available from: [http://www.worldbank.org/wbi/governance/pdf/GovMatters\%20IV\%20main.pdf].

Kennedy, P., 2003. A Guide to Econometrics. Oxford: Blackwell Publishing.

Knack, S. and Keefer P., 1995. "Institutions and Economic Performance: Cross-Country Tests Using Alternative Institutional Measures". Economics and Politics, 7 (3), 207-227.

Koprić, I., 2001. "Državna uprava i lokalna samouprava u Hrvatskoj 1990-2001. - vladavina prava ili politike?". Zbornik Pravnog fakulteta u Zagrebu, 51 (6), 1275-1295.

Kregar, J., 2004. "USKOK je preslab za borbu $s$ korupcijom" [online]. Dostupno na: [http://www.tportal.hr/vijesti/hrvatska/fset.html].

La Porta, R. [et al.], 1999. "The Quality of Government". Journal of Law, Economics and Organization, 15 (1), 222-279.

Leff, N., 1964. "Economic Development Through Bureaucratic Corruption". American Behavioral Scientist, 8-14.

Maddison, A., 2005. "Historical Statistics" [online]. Available from: [http://www.eco.rug.nl/ Maddison/Historical_Statistics/horizontal-file.xls].

Mauro, P., 1995. "Corruption and Growth". Quarterly Journal of Economics, 110 (3), 681-712.

Moers, L., 1999. "Growth Empirics with Institutional Measures and Its Application to Transition Countries: A Survey". Tinbergen Institute Discussion Papers, No. 98-126/2

Murrell, P., 2002. "The Relative Levels and the Character of Institutional Development in Transition Economies" [online]. Available from: [http://ssrn.com/abstract=337082].

Nacionalni program za borbu protiv korupcije s akcijskim planom za borbu protiv korupcije, NN 34/02. Zagreb: Narodne novine.

North, D., 1990. Institutions, Institutional Change and Economic Performance. Cambridge: Cambridge University Press

North, D., 1994. "Economic Performance Through Time". The American Economic Review, 84 (3), 359368.

Orenstein, M. A., 2001. Out of the Red: Building Capitalism and Democracy in Post Communist Europe. Ann Arbor: The University of Michigan Press

Ott, K. (ur.), 2004. Pridruživanje Hrvatske Europskoj uniji - izazovi institucionalnih prilagodbi. Zagreb: Institut za javne financije : Zaklada Friedrich Ebert

Political Risk Services, 2005. "International Country Risk Guide" [online]. Available from: [http://www.icrgonline.com/].

Rivera-Batiz, F. L., 2002. "Democracy, Governance, and Economic Growth: Theory and Evidence". Review of Development Economics, 6 (2), 225-247.

Rodrik, D., 1997. "TFPG Controversies, Institutions, and Economic Performance in East Asia". National Bureau of Economic Research Working Paper, No. 5914.

Rodrik, D., 2003. "Growth Strategies" [online]. Rad pripremljen za objavljivanje u Handbook of Economic Growth. Available from: [http://econ.ucsd.edu/seminars/draft_30.pdf].

Rodrik, D., 2004. "Getting Institutions Right". CESifo DICE Report, 2, 10-15.

Rodrik, D., Subramanian, A. and Trebbi, F., 2004. "Institutions Rule: The Primacy of Institutions over Geography and Integration in Economic Development". Journal of Economic Growth, 9 (2), 131-165.

Rose-Ackerman, S., 2002. Korupcija i vlada - Uzroci, posljedice i reforma. Zagreb: Progres. 
Sachs, J. [et al.], 2004. "Ending Africa's Poverty Trap". Brookings Papers on Economic Activity, (1).

Schönfelder, B., 2004. "Postcommunist judicial system: The deep-rooted difficulties of overcoming communist legacies. With special regard to Croatia". 65th anniversary conference od the Institute of Economics, 18-19 November, Zagreb

Shleifer, A., 1997. "Government in transition". European Economic Review, 41, 385-410.

Svjetska banka, 2003. Ekonomski memorandum za Hrvatsku - Strategija za gospodarski rast kroz europske integracije. Regija Europe i srednje Azije: Odjel za smanjenje siromaštva i ekonomsku politiku, svezak 1.

Štulhofer, A., 2001. "Dynamics of Social Capital 1995-1999" in: Human Development Report Croatia 2001. Zagreb: UNDP, 27-32.

Tanzi, V. and Davoodi, H., 1997. "Corruption, Public Investment, and Growth". International Monetary Fund Working Paper, No. 139.

Tanzi, V., 1998. "Corruption Around the World: Causes, Consequences, Scope and Cures". International Monetary Fund Staff Papers, 45 (4), 559-594.

Theil, H., 1971. Principles of Econometrics. New York: John Wiley

Transparency International Hrvatska, 2005. Istraživanje javnog mnijenja o korupciji, javnosti informacija i sukobu interesa [online]. Anketa na reprezentativnom uzorku građana Hrvatske. Available from: http://www.transparency.hr/dokumenti/istrazivanja/omnibus_04_2005_korupcija.pdf

Transparency International Hrvatska, 2005a. "Gotovo polovica tijela javne vlasti ne poštuje Zakon o pravu na pristup informacijama" [online]. Dostupno na: [http://www.transparency.hr/index.php?id=122].

Transparency International, 2005. Corruption Perceptions Index [online]. Available from: [http://www.transparency.org/surveys/index.html\#cpi].

Uzelac, A., 2001. "Hrvatsko pravosuđe u devedesetima: od državne nezavisnosti do institucionalne krize". Politička misao, 38 (2), 3-41.

Vlada RH, 2003. "Program Vlade Republike Hrvatske u mandatnom razdoblju 2003.-2007." [online]. Dostupno na: [www.vlada.hr].

Wooldridge, J. M., 2002. Introductory Econometrics - A Modern Approach. South-Western College Pub, 2nd ed.

World Bank, 1997. The State in a Changing World. World Development Report 1997. Oxford: Oxford University Press.

World Bank, 2002. The BEEPS II Interactive Dataset: Enterprise Survey in Transition 2002 [online]. Available from: [http://info.worldbank.org/governance/beeps2002/].

World Bank, 2004. Anticorruption in Transition II: Corruption in Enterprise-State Interactions in Europe and Central Asia 1999-2002. Washington: The World Bank. Washington

World Bank, 2005. Doing Business 2005: Removing Obstacles to Growth [online database]. Washington: The World Bank. Available from: [http://www.doingbusiness.org/ExploreTopics/StartingBusiness/CompareAll.aspx].

World Bank, 2005. World Development Indicators [online]. Available from: [http://www.worldbank.org/data/onlinedatabases/onlinedatabases.html].

Zakon o političkim strankama, NN 76/93, 111/96, 164/98, 36/01. Zagreb: Narodne novine.

Zakon o postupku primopredaje vlasti, NN 94/04. Zagreb: Narodne novine.

Zakon o pravu na pristup informacijama, NN 172/03. Zagreb: Narodne novine.

Zakon o sprječavanju sukoba interesa u obnašanju javnih dužnosti, NN 163/03, 94/04, 48/05. Zagreb: Narodne novine.

Zakon o Uredu za suzbijanje korupcije i organiziranog kriminaliteta. Narodne novine, br. 88/01, 12/02. Zagreb: Narodne novine. 


\section{Annex}

Results of econometric analysis: real per capita GDP (PPP) and the rule of law.

Table 1. The whole sample

Dependent variable: $\operatorname{dlog}(\mathrm{GDP})$

Method: GLS (weighted least squares method)

Number of data groups: 4 (95/96, 97/98, 99/00, 01/02)

Number of observations included: 3

Number of countries: 25 (EU-14 + 11 transition countries)

Balanced sample

Total number of panel-observations: 75

t-statistics and standard error are heteroskedastically consistent according to White

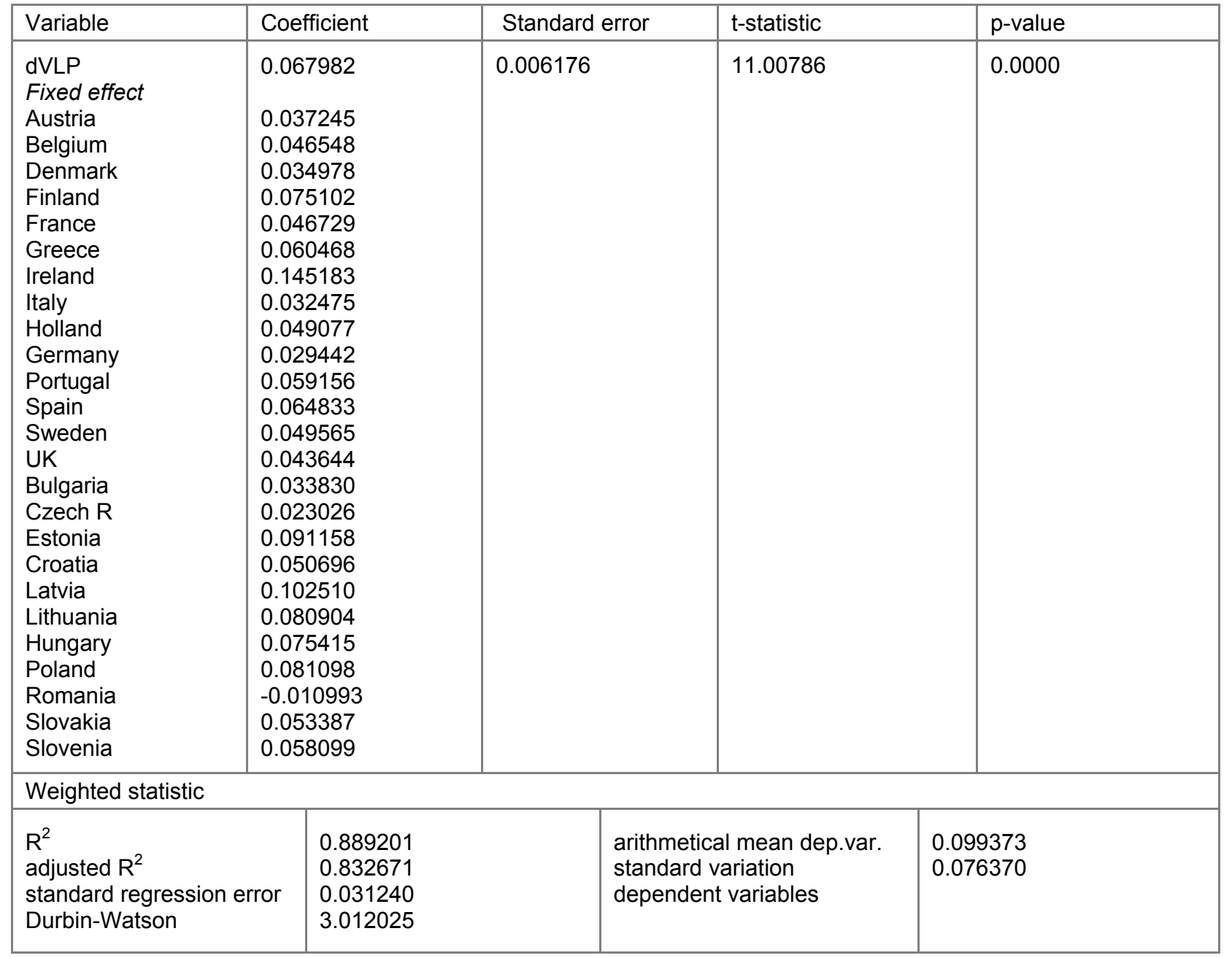


Dependent variable: $\operatorname{dlog}(B D P)$

Method: GLS (weighted least squares method)

Number of data groups: 4 (95/96, 97/98, 99/00, 01/02)

Number of observations included: 3

Number of countries: 14 (EU-14)

Balanced sample

Total number of panel-observations: 42

t-statistic and standard error are heteroskedastically consistent according to White.

\begin{tabular}{|c|c|c|c|c|}
\hline Variable & Coefficient & Standard error & t-statistic & $p$-value \\
\hline $\begin{array}{l}\text { dVLP } \\
\text { Fixed effects } \\
\text { Austria } \\
\text { Belgium } \\
\text { Denmark } \\
\text { Finland } \\
\text { France } \\
\text { Greece } \\
\text { Ireland } \\
\text { Italy } \\
\text { Holland } \\
\text { Germany } \\
\text { Portugal } \\
\text { Spain } \\
\text { Sweden } \\
\text { UK }\end{array}$ & $\begin{array}{l}0.041877 \\
0.037506 \\
0.045503 \\
0.035414 \\
0.075276 \\
0.044727 \\
0.060903 \\
0.145618 \\
0.032301 \\
0.048990 \\
0.028919 \\
0.059330 \\
0.064746 \\
0.049565 \\
0.043383\end{array}$ & 0.005899 & 7.098820 & 0.0000 \\
\hline \multicolumn{5}{|l|}{ Weighted statistic } \\
\hline $\begin{array}{l}\mathrm{R}^{2} \\
\text { adjusted } \mathrm{R}^{2} \\
\text { standard regression error } \\
\text { Durbin-Watson }\end{array}$ & $\begin{array}{l}0.942706 \\
0.912998 \\
0.019802 \\
3.078786\end{array}$ & & $\begin{array}{l}\text { arithmetical mean dep.var. } \\
\text { standard deviation } \\
\text { dependent variables }\end{array}$ & $\begin{array}{l}0.078299 \\
0.067134\end{array}$ \\
\hline
\end{tabular}

Table III Transition Countires

Dependent variable: dlog (BDP)

Method: GLS (weighted least squares method)

Number of data groups: 4 (95/96, 97/98, 99/00, 01/02)

Number of observations included: 3

Number of countries: 11 (transition countries)

Balanced sample

Total number of panel-observations: 33

t-statistic and standard error are heteroskedastically consistent according to White.

\begin{tabular}{|c|c|c|c|c|}
\hline Variable & Coefficient & Standard error & t-statistic & $\mathrm{p}$-value \\
\hline $\begin{array}{l}\text { dVLP } \\
\text { Fixed effects } \\
\text { Bulgaria } \\
\text { Czech R } \\
\text { Estonia } \\
\text { Croatia } \\
\text { Latvia } \\
\text { Lithuania } \\
\text { Hungary } \\
\text { Poland } \\
\text { Romania } \\
\text { Slovakia } \\
\text { Slovenia }\end{array}$ & $\begin{array}{l}0.140082 \\
0.030465 \\
0.019902 \\
0.079862 \\
0.036036 \\
0.095780 \\
0.066003 \\
0.068685 \\
0.076051 \\
-0.014958 \\
0.046417 \\
0.043679\end{array}$ & 0.025281 & 5.541033 & 0.0000 \\
\hline \multicolumn{5}{|l|}{ Weighted statistic } \\
\hline $\begin{array}{l}\mathrm{R}^{2} \\
\text { adjusted } \mathrm{R}^{2} \\
\text { standard regression error } \\
\text { Durbin-Watson }\end{array}$ & $\begin{array}{l}0.865765 \\
0.795451 \\
0.041919 \\
2.892103\end{array}$ & & $\begin{array}{l}\text { arithmetical mean dep.var. } \\
\text { standard deviation dependent } \\
\text { variables }\end{array}$ & $\begin{array}{l}0.106239 \\
0.092685\end{array}$ \\
\hline
\end{tabular}




\section{Results of econometric analysis: real p.c. GDP (PPP) and extent of corruption}

Table IV The whole sample

Dependent variable: dlog(BDP)

Method: GLS (weighted least squares method)

Number of data groups: $4(95 / 96,97 / 98,99 / 00,01 / 02)$

Number of observations included: 3

Number of countries: 25 (EU-14 + 11 transition countries)

Balanced sample

Total number of panel-observations: 75

t-statistic and standard error are heteroskedastically consistent according to White.

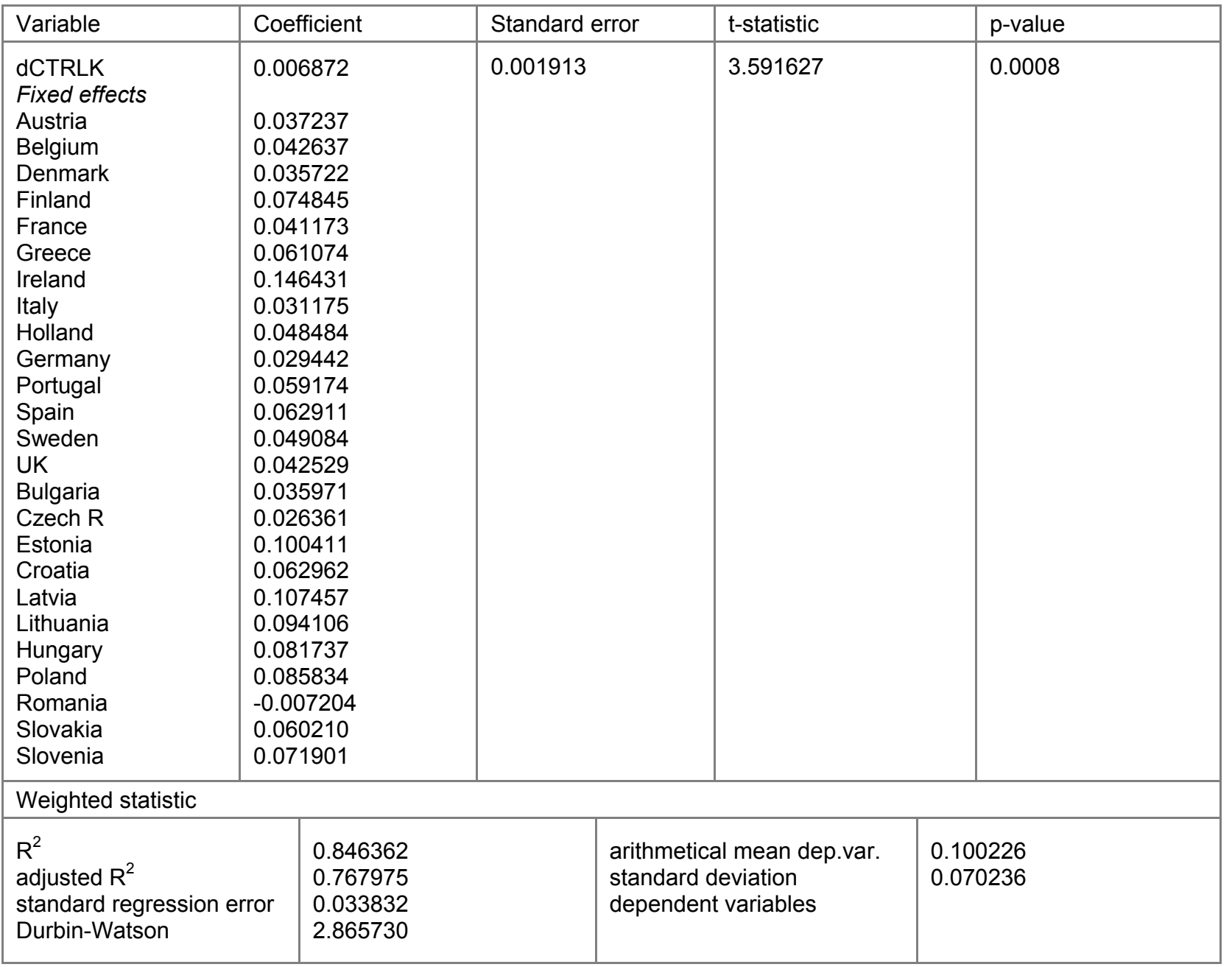


Table V. EU-14

Dependent variable: $\operatorname{dlog}(\mathrm{BDP})$

Method: GLS (weighted least squares method)

Number of data groups: 4 (95/96, 97/98, 99/00, 01/02)

Number of observations included: 3

Number of countries: 14 (EU-14)

Balanced sample

Total number of panel-observations: 42

t-statistic and standard error are heteroskedastically consistent according to White.

\begin{tabular}{|c|c|c|c|c|}
\hline Variable & Coefficient & Standard error & t-statistic & $p$-value \\
\hline $\begin{array}{l}\text { dCTRLK } \\
\text { Fixed effects } \\
\text { Austria } \\
\text { Belgium } \\
\text { Denmark } \\
\text { Finland } \\
\text { France } \\
\text { Greece } \\
\text { Ireland } \\
\text { Italy } \\
\text { Holland } \\
\text { Germany } \\
\text { Portugal } \\
\text { Spain } \\
\text { Sweden } \\
\text { UK }\end{array}$ & $\begin{array}{l}0.001166 \\
0.037808 \\
0.043626 \\
0.036045 \\
0.075434 \\
0.041458 \\
0.061511 \\
0.146336 \\
0.031878 \\
0.048789 \\
0.028012 \\
0.059535 \\
0.064319 \\
0.049483 \\
0.042891\end{array}$ & 0.002078 & 0.560986 & 0.5794 \\
\hline \multicolumn{5}{|l|}{ Weighted statistic } \\
\hline $\begin{array}{l}\mathrm{R}^{2} \\
\text { adjusted } \mathrm{R}^{2} \\
\text { standard regression error } \\
\text { Durbin-Watson }\end{array}$ & $\begin{array}{l}0.903482 \\
0.853436 \\
0.021779 \\
2.950997\end{array}$ & & $\begin{array}{l}\text { arithmetical mean dep.var. } \\
\text { standard deviation } \\
\text { dependent variables }\end{array}$ & $\begin{array}{l}0.076390 \\
0.056889\end{array}$ \\
\hline
\end{tabular}


Dependent variable: $\operatorname{dlog}(B D P)$

Method: GLS (weighted least squares method)

Number of data groups: 4 (95/96, 97/98, 99/00, 01/02)

Number of observations included: 3

Number of countries: 11 (transition countries)

Balanced sample

Total number of panel-observations: 33

t-statistic and standard error are heteroskedastically consistent according to White.

\begin{tabular}{|c|c|c|c|c|}
\hline Variable & Coefficient & Standard error & t-statistic & $\mathrm{p}$-value \\
\hline $\begin{array}{l}\text { dCTRLK } \\
\text { Fixed effects } \\
\text { Bulgaria } \\
\text { Czech R } \\
\text { Estonia } \\
\text { Croatia } \\
\text { Latvia } \\
\text { Lithuania } \\
\text { Hungary } \\
\text { Poland } \\
\text { Romania } \\
\text { Slovakia } \\
\text { Slovenia }\end{array}$ & $\begin{array}{l}0.070508 \\
0.026426 \\
0.029967 \\
0.087472 \\
0.048537 \\
0.094518 \\
0.086257 \\
0.081525 \\
0.085622 \\
-0.003598 \\
0.062544 \\
0.073810\end{array}$ & 0.012944 & 5.44709 & 0.0000 \\
\hline \multicolumn{5}{|l|}{ Weighted statistic } \\
\hline $\begin{array}{l}\mathrm{R}^{2} \\
\text { adjusted } \mathrm{R}^{2} \\
\text { standard regression error } \\
\text { Durbin-Watson }\end{array}$ & $\begin{array}{l}0.899014 \\
0.846117 \\
0.043506 \\
2.702724\end{array}$ & & $\begin{array}{l}\text { arithmetical mean dep.var. } \\
\text { standard deviation } \\
\text { dependent variables }\end{array}$ & $\begin{array}{l}0.128330 \\
0.110905\end{array}$ \\
\hline
\end{tabular}

Table VII. Sources of data

\begin{tabular}{|l|l|}
\hline $\begin{array}{l}\text { Per capita GDP in } \\
1999 \text { international } \\
\text { dollars 1990. }\end{array}$ & Historical Statistics, http://www.eco.rug.nl/ Maddison/Historical_Statistics/horizontal-file.xls \\
\hline Rule of law & World Bank, http://www.worldbank.org/wbi/governance/pdf/govmatters3.pdf \\
\hline Spread of corruption & World Bank, http://www.worldbank.org/wbi/governance/pdf/govmatters3.pdf \\
\hline Starting a company & World Bank, http://www.doingbusiness.org/ExploreTopics/StartingBusiness/CompareAll.aspx \\
\hline $\begin{array}{l}\text { Corruption Perception } \\
\text { Index (CPI) }\end{array}$ & Transparency International, http://www.transparency.org/surveys/index.html\#cpi \\
\hline
\end{tabular}




\section{INSTITUTE OF PUBLIC FINANCE - OCCASIONAL PAPER SERIES}

No. 1 State Intervention for Growth Promotion in Market Economies

Marina Kesner Škreb, January 1997

No. 2 Estimate of Revenues from the Value Added Tax in the Republic of Croatia

Danijela Kuliš and Žarko Miljenović, October 1997

No. 3 The Unofficial Economy in Croatia: Causes, Size and Consequences

Ivo Bićanić and Katarina Ott, November 1997

No. 4 Price Effects of VAT Introduction in Croatia

Martina Dalić, December 1997

No. 5 Tax Administration Reform in Transition: The Case of Croatia

Katarina Ott, April 1998

No. 6 The Present Sate of the Croatian Public Debt

Zoran Bubaš, December 1998

No. 7 Public Investment in Croatia

Katarina Ott and Anto Bajo, March 1999.

No. 8 Welfare Policy and Social Transfers in Croatia

Predrag Bejaković and Alastair McAuley, July 1999

No. 9 Is Unofficial Economy a Source of Corruption?

Vedran Šošić and Michael Faulend, November 1999

No. 10 Banking Sector Problems: Causes, Resolutions and Consequences

Ljubinko Jankov, March 2000

No. 11 Toward a Long - Term Strategy of Economic Development of Croatia: Where to Begin, What to Do, and How to Do It?

Dubravko Mihaljek, June 2001

No. 12 The Underground Economy in Croatia

Katarina Ott, March 2002

No. 13 An Estimate of the Extent of Tax Evasion in Croatia

Sanja Madžarević Šujster, April 2002

No. 14 Opportunism, Institutions and Moral Costs: The Socio - Cultural Dimension of the Underground Economy in Croatia 1995 - 1999

Aleksandar Štulhofer and Ivan Rimac, April 2002

No. 15 Dollarisation and the Underground Economy: Accidental Partners?

Vedran Šošić and Michael Faulend, April 2002

No. 16 Decentralization in the Republic of Croatia - A City Budget in the Period from 1996 to 2000 Mihaela Pitarević, March 2003

No. 17 Inequality in Croatia in the Period from 1973 to 1998

Danijeli Nestić, April 2003 
No. 18 State Aid to Enterprises in Croatia in 2001

Marina Kesner-Škreb, Ivana Pleše and Mia Mikić, October 2003

No. 19 The Role of Parliament in the Budgetary Process - The Example of the Croatian Parliament

Vjekoslav Bratić, October 2004

No. 20 Local Government Unit Borrowing in Croatia: Opportunities and Constraints Anto Bajo, October 2004

No. 21 The Costs of Customs Compliance in Croatia in 2001 Mihaela Bronić, November 2004

No. 22 Tax Compliance Cost of Small Business in Croatia Helena Blažić, November 2004

No. 23 The Compliance Costs of Excise Duties in Croatia Danijela Kuliš, November 2004

No. 24 The Administrative Costs of Taxation and Customs Clearing in Croatia, 1999-2001 Vjekoslav Bratić and Mihaela Bronić, November 2004

No. 25 Fiscal Decentralization in Croatia: Problems of Fiscal Equalization Anto Bajo and Mihaela Bronić, May 2005

No. 26 Income Distribution in Croatia: What Do the Household Budget Survey Data Tell Us? Danijel Nestić, June 2005

No. 27 Impact of Foreign Direct Investment on Croatian Manufacturing Exports Goran Vukšić, June 2006

No. 28 Managing the Cash and Liquidity of the Croatian Budget Anto Bajo, June 2006

No. 29 The Quality of Governance and Economic Growth in Croatia Marijana Bađun, June 2006 


\section{ABOUT THE INSTITUTE OF PUBLIC FINANCE}

The Institute of Public Finance (Zagreb, Croatia) founded in 1970, is a public institution dealing with research in the field of public sector economics, but also in applied and theoretical research on broader set of economic topics such as economic growth and development, role of institutions, transition to the market economy and EU integration. The empirical analysis is preferably related, but not limited, to experience of countries in Central and Eastern Europe and Southeast Europe.

\section{SELECTED LIST OF PUBLICATION (in English)}

\section{Serial publications}

- Financial Theory and Practice

- Occasional Paper Series

- Newsletter

\section{Books}

- Croatian Accession to the European Union: Facing the Challenges of Negotiations, editor Katarina Ott, 2005.

- The competitiveness of Croatia's human resources, editors Predrag Bejaković and Joseph Lowther, 2004.

- Croatian Accession to the European Union: Institutional Challenges, editor Katarina Ott, 2004.

- The Croatian Tax System, editor Mirjana Jerković, 2003.

- Croatian Accession to the European Union: Economic and Legal Challenges, editor Katarina Ott, 2003.

- The Citizen's Guide to Taxation, Marina Kesner-Škreb and Danijela Kuliš, 2001, (updated online).

- A Citizen's Guide to the Budget, editor Katarina Ott, 2000.

For further insight in our publications and ordering information please visit:

http://www.ijf.hr/eng/index.html. 